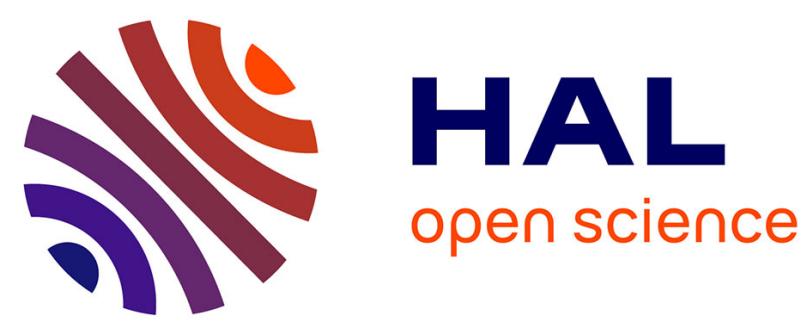

\title{
FIBROBLAST GROWTH FACTOR (FGF) IMPLICATION IN THE NEONATAL DEVELOPMENT OF THE COCHLEAR INNERVATION
}

\author{
G. Després, I. Jalenques, R. Romand
}

\section{To cite this version:}

G. Després, I. Jalenques, R. Romand. FIBROBLAST GROWTH FACTOR (FGF) IMPLICATION IN THE NEONATAL DEVELOPMENT OF THE COCHLEAR INNERVATION. Journal de Physique IV Proceedings, 1992, 02 (C1), pp.C1-173-C1-176. 10.1051/jp4:1992134 · jpa-00251205

HAL Id: jpa-00251205 https://hal.science/jpa-00251205

Submitted on 1 Jan 1992

HAL is a multi-disciplinary open access archive for the deposit and dissemination of scientific research documents, whether they are published or not. The documents may come from teaching and research institutions in France or abroad, or from public or private research centers.
L'archive ouverte pluridisciplinaire HAL, est destinée au dépôt et à la diffusion de documents scientifiques de niveau recherche, publiés ou non, émanant des établissements d'enseignement et de recherche français ou étrangers, des laboratoires publics ou privés. 


\title{
FIBROBLAST GROWTH FACTOR (FGF) IMPLICATION IN TIIE NEONATAL DEVELOPMENT OF THE COCHLEAR INNERVATION
}

\author{
G. DESPRES, I. JALENQUES and R. ROMAND \\ Laboratoire de Neurobiologie et Physiologie du Développement, Université Blaise Pascah \\ F-63177 Aubière cedex, France
}

The presence of fibroblast growth factor-like protein has been investigated on cryostat sections from Sprague Dawley rat cochleae and auditory brainstem nuclei of various neonatal stages by indirect immunofluorescence and immunoperoxydase techniques with an antibody directed against the 1.24 amino-acid sequence of brain derived basic FGF. bFGF-like immunoreactivity could already be detected in the neonatal cochlea at the hair cell level and in spiral ganglion neurons. Intraganglionic spiral bundle was not immunoreactive. In the brainstem, FGF was localized in the cochlear nucleus and in the superior olivary complex. Since spiral ganglion and cochlear nucleus neurons are labelled, it is possible that bFGF is one of the trophic factors involved in cochlear innervation of receptors and more specifically to afferent innervation.

\section{Introduction}

The onset of auditory innervation is complex and presents phases of growth, differentiation, cell death, plasticity and survival that may be mediated by several growth factors. In vitro studies of the otocyst have suggested that trophic interactions might occur between cochleovestibular ganglion cells and their target, the auditory hair cells $(1,2,3)$. The differentiating hair cells might provide trophic cues for directing the ingrowth of stato-acoustic ganglion dendrites $(4,5)$. The most fully characterized trophic factor that can locally control the extension of the peripheral ganglion cells processes is the nerve growth factor (NGF) $(6,7,8)$ and recent evidences suggest that NGF may play a role in the development of the auditory innervation. NGF-like immunoreactivity has been detected in hair cells of the rat organ of Corti during the postnatal period (9) and NGF-receptor (NGF-R) has been localized in cochlear and brainstem structures related to the efferent auditory innervation (10). In vitro experiments have shown that during the early development of the inner ear, NGF could be implicated in the survival of cochleovestibular ganglion neurons (11).

Basic fibroblast growth factor (bFGF) has been established as a potent neurotrophic protein. It occurs in the brain $(12,13)$ and promotes in vitro survival of several embryonic peripheral and central neuron populations $(14,15,16)$. bFGF has also been shown to increase choline acetyl tranferase expression in cultured septal neurons (17) and bFGF perfusion into cerebral ventricles rescues fimbria-fornix transected basal forebrain cholinergic neurons (18).

The purpose of this work is to evaluate the possible presence of bFGF in the cochlea and in the auditory brainstem nuclei of the postnatal rat.

\section{Materials and Methods}

The study was carried out, on at least 5 animals at each stage, at birth (PDO) and postnatal day 3 (PD3). Animals were decapitated, cochleae and auditory brainstems (slice of brainstem containing cochlear nucleus and superior olivary complex) were quickly dissected and fixed for one hour in $4 \%$ 
paraformaldehyde in phosphate butfered saline (PBS). After several washes in PBS, organs were cryoprotected overnight in a bath of $20 \%$ sucrose in PBS and serially sectionned at $10 \mu \mathrm{m}$ on a freezing microtome.

Primary rabbit antibody against the fraction 1-24 of the brain bFGF was provided by $\operatorname{Dr} A$. Baird. The sections were incubated overnight with this antibody, diluted $1 / 200$ in $5 \%$ normal goat serum, $0,1 \%$ saponin in PBS, and rinsed 3 times in PBS. Brainstem sections were treated with biotinylated goat anti-rabbit IgG antibody (Sigma) diluted 1/400 in PBS for one hour, rinsed in PBS, incubated with Extravidin-peroxydase complex (Sigma) diluted 1/800 in PBS for one hour, rinsed in PBS, immersed in $0,05 \% \mathrm{DAB} / 0,01 \% \mathrm{H} 2 \mathrm{O} 2$ in PBS solution for $7 \mathrm{~min}$, rinsed, dehydrated and mounted. Sections of the cochlea were incubated in rodamine labelled goat anti-rabbit lgG antibody (Sigma) diluted $1 / 200$ in PBS for two hours, rinsed in PBS, mounted in $50 \%$ Glycerol in PBS. Controls of specificity were carried out by routinely omitting anti-bFGF antibody or by absorbing it overnight with an excess of fraction 1-24 of bFGF (Peninsula Laboratories).

Results

During the neonatal period, a faint bFGF-like immunoreactivity is well visible in the cytoplasm of inner hair cells and in fibers that reach the sensory epithelium (Fig. 1). A stronger immunostaining affects the cytoplasm of spiral ganglion neurons, but intraganglionnic spiral bundle (IGSB) fibers are not reactive (Fig. 2). In the Scarpa's ganglion, vestibular ganglion neurons are strongly positive (Fig. 3).

In the brainstem, bFGF-like labelling is seen on numerous cell bodies in the central region and granular part of the ventral cochlear nucleus (VCN) (Fig. 4), in the dorsal cochlear nucleus (not shown), in some auditory nerve fibers (Fig. 4). Some perikaria are stained in the superior olivary complex (SOC) (Fig. 5). Several other structures such as vestibular nuclei, facial nucleus and trigeminal motor nucleus were also immunostained (not shown).

No immunostaining was observed when primary antibody was omitted or immunoabsorbed with $1-24$ bFGF.

\section{Discussion}

Present results show for the first time the presence of bFGF-like protein in the lower auditory tract during the neonatal period. Our control tests confirm the specificity of the antibody utilized and reported by others $(19,20)$. Previous findings $(14,15,16,17,18)$ have suggested that bFGF could act as a neurotrophic factor. In the neonatal cochlea the labelling of inner hair cells and spiral ganglion neurons could indicate that bFGF might be produced by the sensory epithelium and might assume the maintenance of primary afferent auditory neurons. These neurons, which do not seem NGF dependent at this stage, could need another factor essential for their development and/or survival, ie: bFGF. However, the demonstration of bFGF transport from target tissue to the neuron by neuronal extensions remains to be established in the nervous system. Question is raised by the different staining observed between inner and outer hair cells, even though they have, at this stage, a similar afferent innervation pattern (21). This difference may be related to variation of maturity between the two types of receptors.

In the brainstem, bFGF is widely distributed in various nuclei. Most stuctures in relation to the inner ear are immunoreactive. A large distribution of FGF-receptor (FGF-R) mRNA have also been reported in the adult rat brain (22).

VCN cell bodies are bFGF immunoreactive and this seems to be correlated with the presence of bFGF-R mRNA in the VCN in the adult rat (22). This nucleus also expresses NGF-R protein $(10,23)$ and NGF-R mRNA (24) but we do not yet know if expressions of these growth factors are related to the same cells.

Efferent fibers, which come from SOC through the IGSB, are not labelled by bFGF antibody, even though some neurons in the SOC express bFGF. A recent study with the same antibody, reports the presence of bFGF staining in the SOC of the rat at PD 28 and adult stage (20). In a previous report (10) NGF-R has been localized in IGSB and-SOC during this period and we have suggested that cholinergic efferent system could be NGF-dependent. 

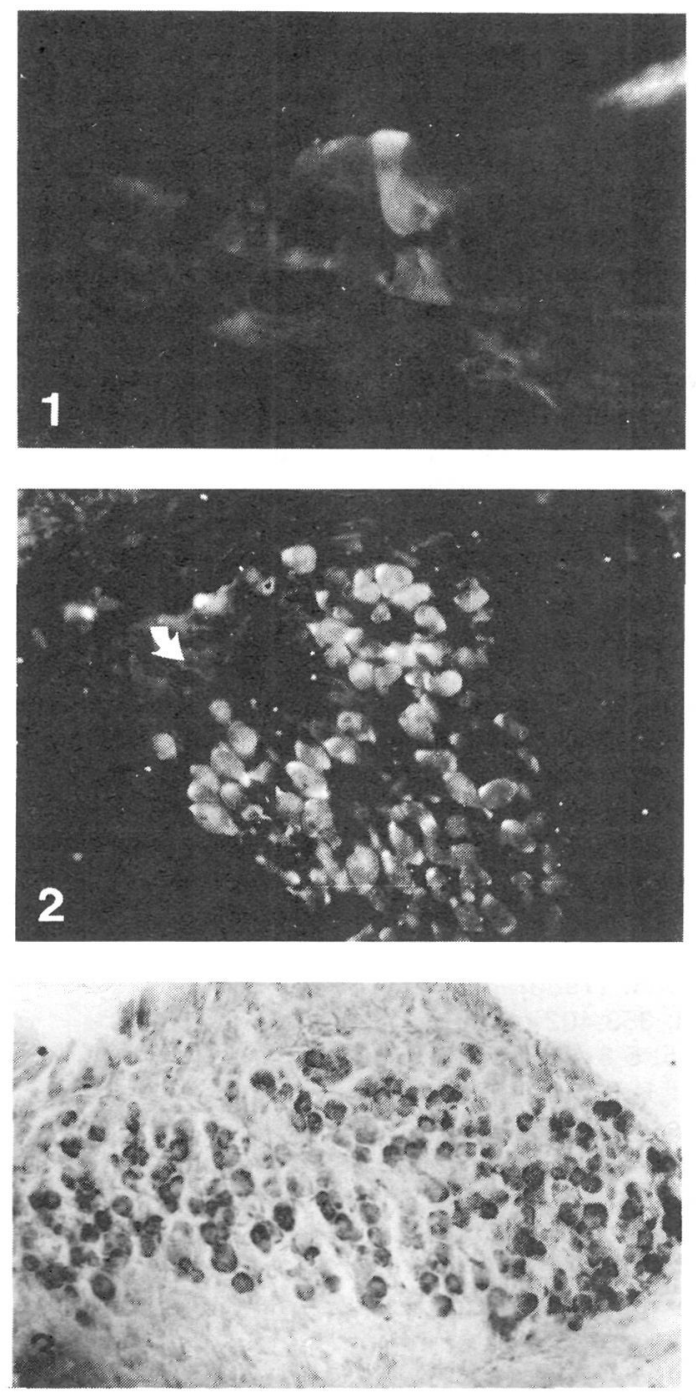
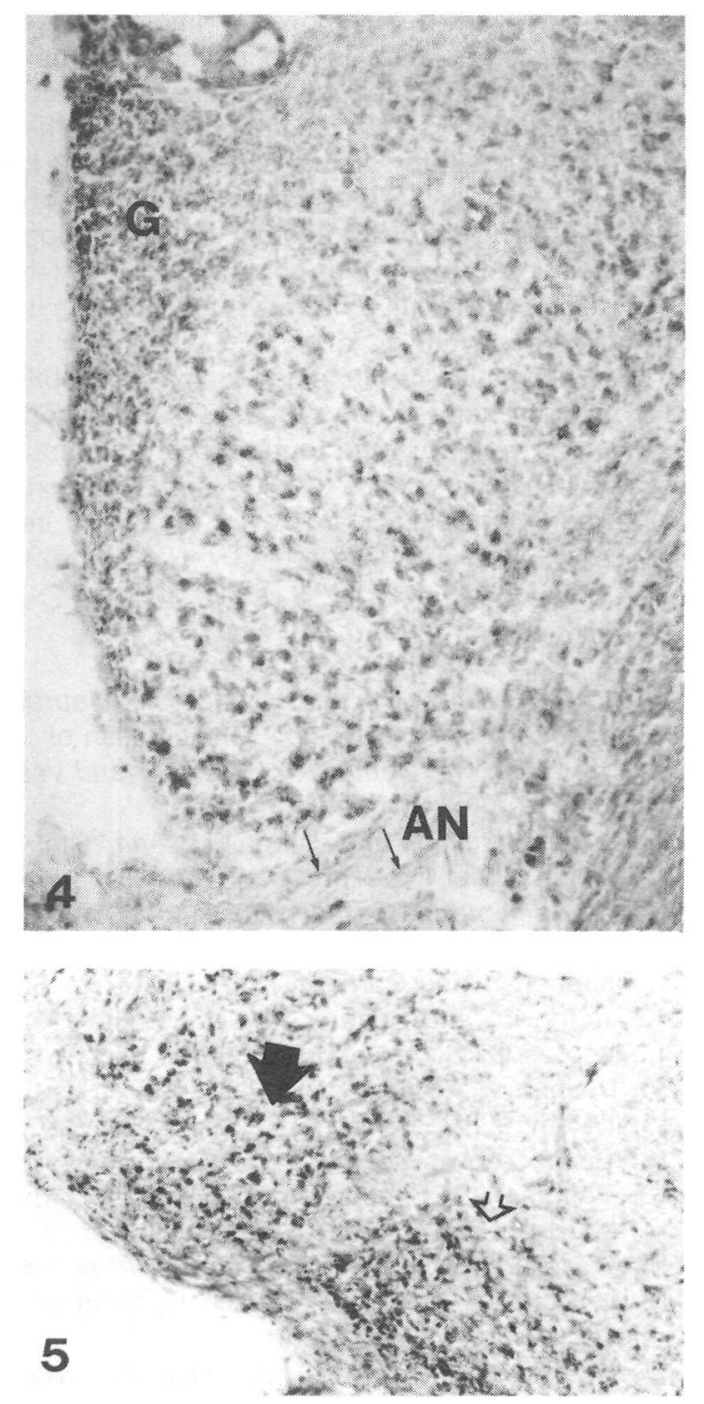

bFGF-like immunostaining in the lower auditory tract of the neonatal rat.

Fig. 1: Cross section through the basal turn of the organ of Corti at PDO; a faint bFGF-like immunoreactivity is well visible in the cytoplasm of inner hair cells.

Fig. 2: Cross section through the first turn of the spiral ganglion at PD3; immunostaining affects the cytoplasm of spiral ganglion neurons, intraganglionnic spiral bundle fibers (arrow) are not reactive.

Fig. 3: Cross section through the Scarpa's ganglion at PDO; vestibular ganglion neurons are bFGFlike positive.

Fig. 4: Cross section through the antero ventral cochlear nucleus at PD3; bFGF-like labelling is present on numerous cell bodies in the central region and granular part $(G)$ of the nucleus and in auditory nerve (AN) fibers (arrows).

Fig. 5: Cross sections through the superior olivary complex at PD 3; some perikaria are stained in lateral superior olive complex (arrow) and in superior paraolivary nucleus (open arrow). 
FGF has been shown to interact specifically with the excitatory neurotransmitter glutamate (25). Since glutamate is one of the main neurotransmitters of auditory nerve fibers afferent to the VCN (26), localization of FGF-like immunoreactivity and FGF-R mRNA to the cochlear nucleus suggests that FGF and glutamate could act in the same cells.

Several interpretations can be proposed for the coexistence of bFGF and NGF-R in some auditory nuclei. It is possible that some sets of neurons require bFGF and others require NGF, or these two factors may address identical neuronal population as reported for septal neuron in vitro (17). Another possibility is that some neurons are NGF-dependent and could need bFGF as an additional growth factor for their survival. Lastly, as suggested by the astrocyte model (27), bFGF could stimulate the synthesis of NGF.

The results of this study indicate that bFGF is widely distributed in the lower auditory tract in the neonatal stage of the rat. Then bFGF may play a significant role in the development of the auditory system as well as in the regulation of neuronal maintenance and plasticity in the adult auditory system. The coexistence of bFGF and NGF-R in the brainstem auditory nuclei could suggest a complementary biological role for these two nervous growth factors.

This work was supported by INSERM (896013) and Fondation pour la Recherche Médicale

\section{References}

1. Ard MD, Morest DK and Hauger SH. Neuroscience 16: 151-170 (1985).

2. Sobkowicz HM and Rose JE. Innervation of the organ of Corti of the fetal mouse in culture. In: R. Romand, Ed. Development of Auditory and vestibular systems; New York: Academic Press 1983: $27-$ 45.

3.Van de Water TR and Ruben RJ. Ann. Otol. Rhinol. Laryngol. 93: 558-564 (1984).

4. Van de Water TR. Ann. Otol. Rhinol. Laryngol. Suppl. 33: 1-32 (1976).

5. Van de Water TR. Hear. Res. 22: 265-277 (1986).

6. Levi-Montalcini R and Angeletti PU. Physiol. Rev. 48: 534-569 (1968).

7. Thoenen H and Barde YA. Physiol. Rev. 60:1284-1335. (1980).

8. Greene LA and Shooter EM. Annu. Rev. Neurosci. 3: 353-402 (1980).

9. Després G, Giry N and Romand R. Neurosci. Lett. 85: 5-8 (1988).

10. Després G, Hafidi A and Romand R. Hear. Res. 52: 157-166 (1991).

11. Lefebvre PP, Leprince P, Weber T et al. Brain Res. 507: 254-260 (1990).

12. Gospodarowicz D, Neufeld G and Schweigerer L. Moll. Cell. Endocrinol. 46: 187-204 (1986).

13. Pettmann B, Labourdette G., Weibel M. et al. Neurosci. Lett. 68: 175-180 (1986).

14. Morrison RS, Sharma a, de Vellis $J$ et al. Proc. Natl. Acad. Sci. USA 83: 7537-7541 (1986).

15. Walicke P, Cowman WM, Ueno $N$ et al. Proc. Natl. Acad. Sci. USA 83: $3012-3016$ (1986).

16. Unsicker K, Reichert-Preibsch H, Schmidt R et al. Proc. Natl. Acad. Sci. USA 84:5459-5463

(1987).

17. Grothe C, Otto D and Unsicker K. Neuroscience 31: 649-661 (1989).

18. Anderson KJ, Dam D, Lee $S$ et al. Nature 332: 360-361 (1988).

19. Gonzalez AM, Buscaglia M, Ong M et al. J. Cell Biol. 110: 753-765 (1990).

20. Grothe C, Zachmann K and Unsicker K. J. Comp. Neurol. 305: 328-336 (1991).

21. Lenoir M, Shnerson A and Pujol R. Anat. Embryol. 160: 253-262 (1980).

22. Wanaka A, Johnson EM and Milbrandt J. Neuron 5: 267-281(1990).

23. Yan $Q$ and Johnson EM. J. Neurosci. 8: 3481-3498 (1988).

24. Kho S, Oyler GA and Higgins GA. Exp. Neurol. 106: 209-221 (1989).

25. Mattson MP, Murrain M, Guthrie PB et al. J. Neurosci. 9: 3728-3740 (1989).

26. Caspary DM. Cochlear nuclei: functional neuropharmacolology of the principal cell types. In: Altschuler RA, Hoffman DW, Bobbin RP, eds. Neurobiology of Hearing: The Cochlea. New York: Raven Press, 1986: 303-332.

27. Yoshida K and Gage FH. Brain Res. 538: 118-126 (1991). 